\title{
GibbsBoost 顔検出と映像監視業務への応用
}

\author{
A GibbsBoost Face Detector and its Application to \\ Facial Occlusion Spotting
}



\author{
Atsushi Matsui ${ }^{\dagger \dagger}{ }^{\dagger \dagger}$, Yu Goto ${ }^{\dagger \dagger}$, Akio Kimura ${ }^{\dagger \dagger}$, \\ Yohei Nakada ${ }^{\dagger \dagger}$, Takashi Matsumoto ${ }^{\dagger \dagger}$, \\ Simon Clippingdale ${ }^{\dagger}$, Mahito Fujii ${ }^{\dagger}$ and Nobuyuki Yagi $^{\dagger}$
}

\begin{abstract}
We propose non-deterministic methods for automatically detecting occlusions of people's faces by superimposed symbols. We trained a face detector using an ensemble-learning algorithm (GibbsBoost) that is based on the sequential Monte Carlo method. We implemented an occlusion detector using a mixture of two discriminant functions that were related to the size of the detected face region and the occluded face area. One realization of this detector achieved a true positive detection rate of $90 \%$. We present experimental results and discuss possibilities for further improvements.
\end{abstract}

キーワード : 放送映像, 映像多重, 遮蔽状態判別, 顔画像検出, GibbsBoost

\section{1. ま え がき}

近年の計算機環境の急速な発展と低廉化に伴い, 放送で も CG が多く使われるようになり，実写映像（素材映像） に文字や画像を重ねる演出が多用されるようになっている. 例えば，早朝の時間帯での NHK・民放各局の二ュース番組 では，天気予報のマークやテロップを素材胦像に多重（スー パーインポーズ）する演出が行われている。このような補 助的な映像情報を素材映像に多重する演出は，しばしば番 組が本来伝えようとしている被写体の遮蔽をもたらす．放 送番組における具体的な被写体としては，様々な対象物が 考えられるが，人物の顔は多くの放送コンテンツに共通か つ重要な被写体であり，スーパーインポーズによる遮蔽が 番組の品質に及ぼす影響が特に大きい.

番組制作の現場では，こうした演出が引き起こす予期せ 遮蔽を回避するためオペレータが目視にもとづき手動で 対応しているが，手作業に頼った番組の管理・監視方式は,

2007 年 3 月 9 日, 動的画像处理実利用化ワークショップ (DIA2007) で発表 2007 年 3 月 27 日受付, 2007 年 11 月 27 日再受付, 2007 年 12 月 20 日 採録

$\dagger$ NHK 放送技術研究所

(† 157-8510 世田谷区砧 1-10-11, TEL 03-5494-3384)

††早稲田大学 理工学術院

(干 169-8555 新宿区大久保 3-4-1, TEL 03-5286-3377)

† NIIK Science and Technical Research Laboratories

(1-10-11, Kinuta, Setagaya-ku, Tokyo, 157-8510 Japan)

$\dagger \dagger$ Faculty of Science and Engineering, Waseda University

(3-4-1, Ohkubo, Shinjuku-ku, Tokyo, 169-8555 Japan)
オペレータの精神的疲労や判断の個人差など不確定な要素 を抱えているため，安定化・省力化などの観点から，遮蔽 の自動検知システムを望む声は強い。

本研究では, 確率的な集団学桨アルゴリズム (GibbsBoost）にもとづく顔画像検出と，顔検出結果の誤差や顔 内部の視覚的重要度の分布を考慮した遮蔽状態判別を組み 合せることで，映像多重に伴う素材映像中の人物の顔の遮 蔽を高精度に検知する手法を提案する.

\section{2. 方 式 概 要}

放送映像は，多くの場合，複数の放送素材映像をもとに して制作される，本稿では，番組送出の際に，主たる素材 映像（主素材映像）に補助的な映像（副素材映像）を多重 する過程について考える．本研究の日的は，与えられた主 素材映像に出現した人物の顔が，副素材映像の多重によっ て遮蔽されるか否かを自動的に判定することである。

本稿で想定する遮蔽判定方式の概要を図 1 に示す。本方 式は，主素材映像中の顔を検出する顔画像検出と，検出し た各々の顔についての遮蔽状態の判定を行う遮蔽状態判定 の二つの処理部から構成される，以後，本研究で扱う検知 対象と，各々の処理の詳細について述べる.

\section{3. 検 知 対 象}

実際の放送において検知すべき遮蔽状態には様々な状況 が含まれるが，本研究では，多くの放送番組に抢いて主要 


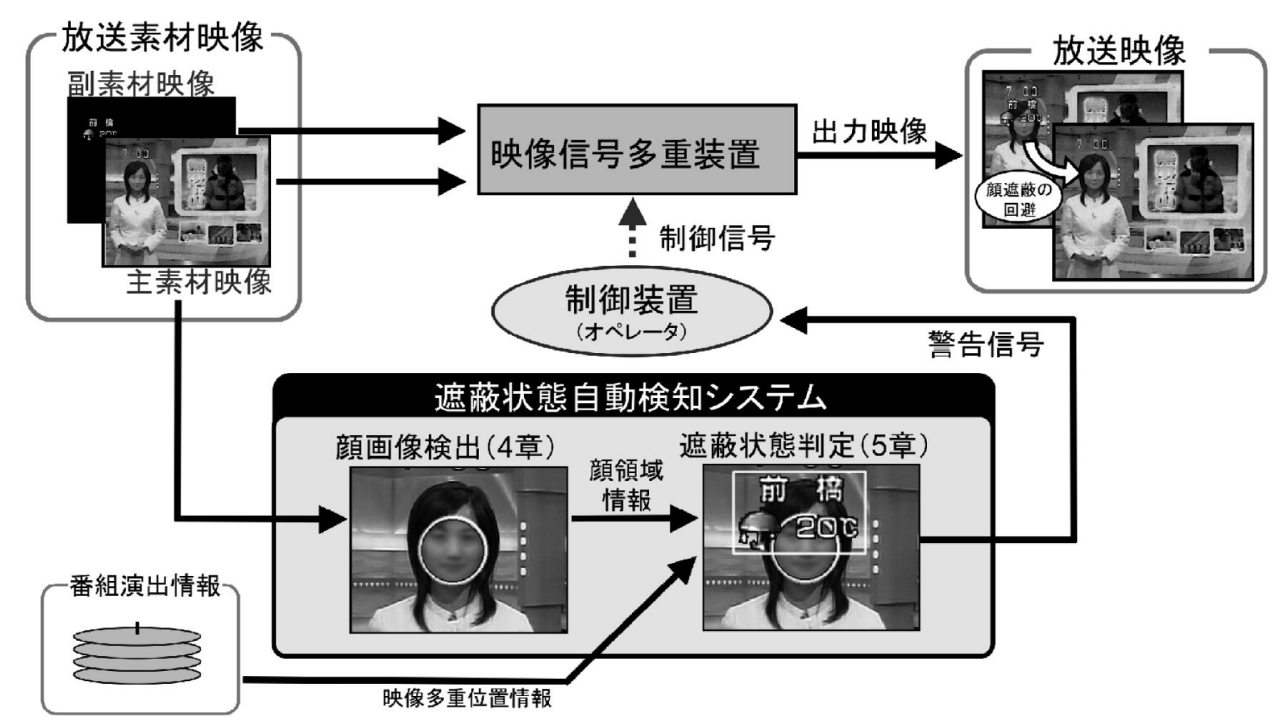

図 1 顔遮蔽判定方式の概要図

Architecture of face occlusion spotting system.

かつ頻繁に出現する人物の顔に注目し, 次の三つの条件を 満たす映像を検知対象とする.

（1）画面上の顔画像の大きさが一定以上

（2）被遮蔽領域の顔全体に占める割合が一定以上

（3）遮蔽状態が一定期間に渡り連続的に発生

(1) は，被写体の画面上の大きさに関する条件であり，放送 コンテンツにおける主要人物が，その他の人物（群衆）よ りも大きなサイズで撮影される一般的な傾向を反映したも のである。(2) は，遮蔽状態の度合いの強弱に関する条件 であり, 遮蔽による映像情報の欠落が, 被遮蔽領域が被写 体（顔）全体に占める面積の比に応じて増大するという自 然な仮定にもとづく. (3) は，カメラワークや被写体自身の 動き等に起因する一時的な遮蔽を検知対象から除外するた めの, 遮蔽状態の時間的連続性に関する条件である。この 条件は, 放送映像への映像多重のオン・オフ操作の頻繁な 繰り返しによって視聴者に与える視覚的ストレスを, 最低 限に抑えるために放送現場でとられている実際の運用方針 に合致する。

本稿では, 統計的手法にもとづき学習した顔画像検出器 と, これら三つの条件を反映した遮蔽状態判別器を用いて, 放送素材映像に出現した顔の遮蔽を自動的に検知する手法 を提案する.

\section{4. 顔 画 像 検 出}

两像から人物の顔を検出する技術には，ニューラルネッ トワークを用いる手法 ${ }^{1)}$ や， サポートベクターマシンを用 いる手法 ${ }^{2)}$ など, 様々な手法が提案されている. しかし， それらの多くは特徴量として各两素の輝度值を用いるため, 照明条件の変動やノイズの影響を受けやすい.

本研究では, これらの変動に対して頑健で, かつ高速演 算が可能な矩形差分特徵 ${ }^{3)}$ を用いた比較的単純な識別機 (弱学習機) を多数用意し, それらの組合せ最適解を集団
学習アルゴリズムを用いて逐次的に求める ${ }^{4)}$. 集団学習の 具体的アルゴリズムとしては, 学習データについての判別 エラーの期待值（損失関数）を最小化する弱学習機を母集 団から順に抽出し, 解を逐次的かつ決定論的に求める手法 $\left(\right.$ AdaBoost $\left.{ }^{5}\right)$ ) が一般的である. しかし, 逐次的に解を求 める過程に扔いて, 最終的に損失関数が最小となる解（最 適解）よりも，その他の解の損失関数の值が一時的に小さ くなる場合も起こり元るが，この手法は各段階における損 失関数が最小となる解を一つだけ保持しつつ探索を進める ため, 最終的に得られる解は一般には最適解とはならない.

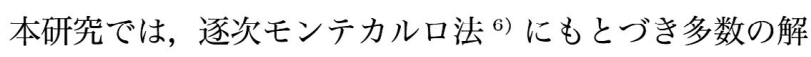
の候補を保持しつつ探索を行う確率的逐次探索アルゴリズ ム $\left(\right.$ GibbsBoost $\left.^{7)}\right)$ を適用することで, 逐次探索の過程で 最適解が棄却される危険性を抑制する。一般のブースト学 習アルゴリズムと提案手法の概念図を図 2 に示す。

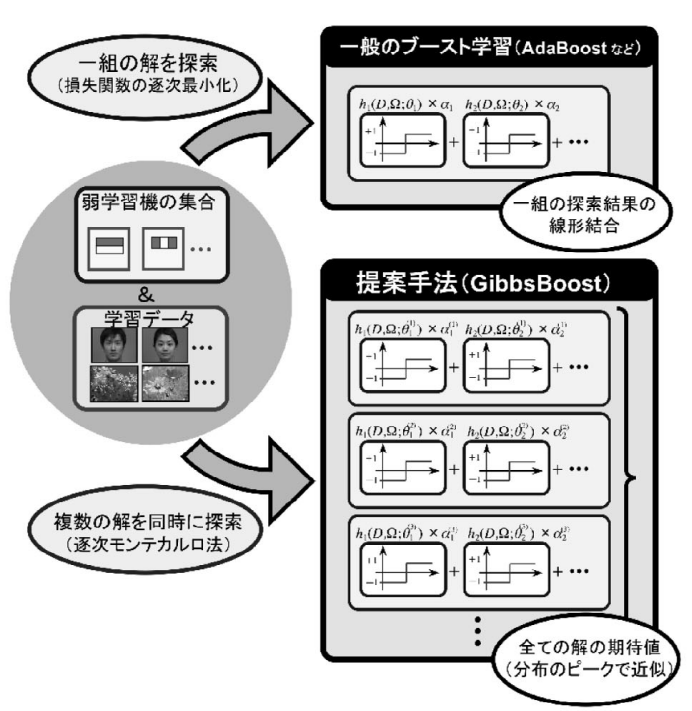

図 2 GibbsBoost 学習アルゴリズムの概念図 Overview of GibbsBost learning algorithm. 
$S$ 個の弱学習機（弱仮説） $h_{1}, \ldots, h_{S}$ の線形結合で構成 された判別機 $F_{S}$ について考える.

$$
F_{S}\left(D_{k}, \Omega_{i} ; \Theta_{S}\right)=\sum_{s=1}^{S} \alpha_{s} h_{s}\left(D_{k}, \Omega_{i} ; \theta_{s}\right) .
$$

ここで, $D_{k}$ は $k$ 番目の入力画像をあらわし,$\Omega_{i}=$ $\left\{x_{i}, y_{i}, r_{i}\right\}$ は入力画像 $D_{k}$ 上の中心位置 $\left(x_{i}, y_{i}\right)$, 大き さ (半径) $r_{i}$ なる顔候補領域をあらわす。また， $\Theta_{S}=$ $\left(\alpha_{1}, \ldots, \alpha_{S}, \theta_{1}, \ldots, \theta_{S}\right)$ は, 1 番目から $S$ 番目までの各々 の弱学習機の信頼度 $\alpha_{1}, \ldots, \alpha_{S}$ とパラメータ $\theta_{1}, \ldots, \theta_{S}$ の 組をあらわす。

通常のブースト学習アルゴリズムでは，両目の位置を基準 として，あらかじめ一定の領域 $\overline{2}$ に位置と大きさを正規化 した $K$ 組の学習デー夕 $\left\{\left(D_{k}, \bar{\Omega}\right), \eta_{k}\right\}_{k=1}^{K}, \eta_{k} \in\{-1,1\}$ が 与えられたとき, 損失関数の和の逐次最小化を考える（図 2 上段）が, GibbsBoost では，損失関数 $L\left(z_{k}\right)=\exp \left(-z_{k}\right)$ をエネルギー関数として用いた Gibbs 分布を考え，パラ メー夕の確率分布を定義する.

$$
P\left(\Theta_{S}\right) \propto \pi\left(\Theta_{S}\right) \exp \left\{-\beta_{S} \sum_{k=1}^{K} L\left(\eta_{k} \frac{F_{S}\left(D_{k}, \bar{\Omega} ; \Theta_{S}\right)}{\sqrt{S}}\right)\right\} .
$$

そして，この確率分布に従う $M$ 本のサンプル系列 $\left\{\Theta_{S}^{(m)}\right\}_{m=1}^{M}$ を逐次モンテカルロ法を用いて抽出する (図 2 下段)。ここで, $\pi\left(\Theta_{S}\right)$ は $\Theta_{S}$ のとりうる範囲に定義された 確率密度関数であり, ベイズ学習の事前確率分布に相当す る. 本稿では, 矩形特徵の配置に関する主観的・先験的情報 にもとづき，顔の中心部にピークをもつ正規分布 ${ }^{8)}$ をい る. 最終的な判別機 $F_{S}$ は, パラメータの確率分布 $P\left(\Theta_{S}\right)$ についての期待值で定義される。

$$
\begin{aligned}
F_{S}\left(D_{k}, \bar{\Omega}\right) & =\int F_{S}\left(D_{k}, \bar{\Omega} ; \Theta_{S}\right) P\left(\Theta_{S}\right) d \Theta_{S} \\
& \cong \frac{1}{M} \sum_{m=1}^{M} F_{S}\left(D_{k}, \bar{\Omega} ; \Theta_{S}^{(m)}\right) .
\end{aligned}
$$

このとき, 未知の入力画像 $D_{t}$ に対して任意の顔候補領域 $\Omega_{i}$ が顔であるか否かを判定する顔倹出器 $H_{S}\left(D_{t}, \Omega_{i}\right)$ は次 式で与えられる。

$$
H_{S}\left(D_{t}, \Omega_{i}\right)=\operatorname{sign}\left(F_{S}\left(D_{t}, \Omega_{i}\right)\right) .
$$

式 (3) の期待值計算における確率分布のピーク以外の寄 与が無視できるほど小さい場合, 判別機 $F_{S}\left(D_{k}, \bar{\Omega}\right)$ は確率 最大のサンプル $\Theta_{S}^{*}$ を用いて次式で近似可能である:

$$
\begin{aligned}
& F_{S}\left(D_{k}, \bar{\Omega}\right) \cong F_{S}\left(D_{k}, \bar{\Omega} ; \Theta_{S}^{*}\right), \\
& \Theta_{S}^{*}=\underset{\Theta_{S} \in\left\{\Theta_{S}^{(m)}\right\}_{m=1}^{M}}{\arg } \max \log \left(\Theta_{S}\right) .
\end{aligned}
$$

顔画像検出における上式の近似の妥当性を調べるため, それぞれの計算法について比較実験を行った（式 (3)：cxpectations, 式 (5): max. prob.).さらに, GibbsBoost $ア$ ルゴリズムの有効性を検証するため, AdaBoostで学習し

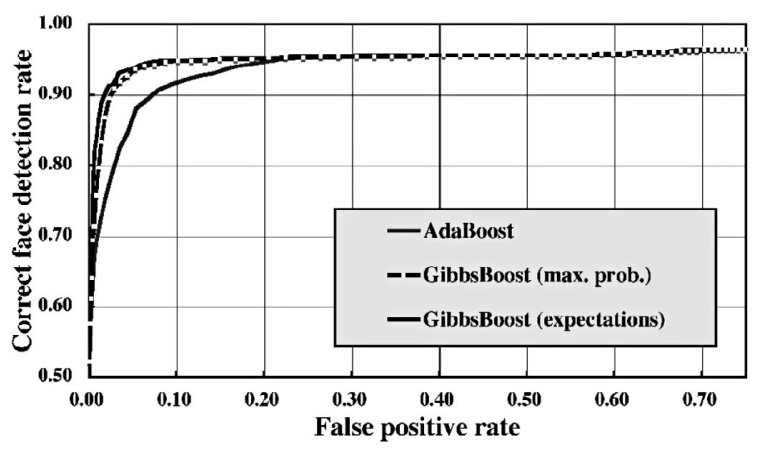

図 3 顔画像検出結果の比較 (GibbsBoost/AdaBoost) face detection results of GibbsBoost and AdaBoost.

た顔倹出器についての顔倹出実験もあわせて行った（AdaBoost）。なお, 各々の顔検出器の評価には CMU-MIT 顔 画像データベース ${ }^{1)}$ を, 学習には web から収集した画像 デー夕（顔画像：5000 枚，非顔画像：10000 枚）をそれぞれ 用いた。 また弱学習器長は $S=500$ に統一し, GibbsBoost で抽出するサンプル数は $M=500$ とした。

顔検出実験の結果を図 $\mathbf{3}$ に示す。GibbsBoost の ROC 曲線は 2 本とも AdaBoost の曲線の上の領域を通過してお り, 提案手法による改善効果が確認された。一方, 2 本の GibbsBoost の曲線は図 3 上でほぼ重なっており，式 (5)に よる期待值の近似による影響は, AdaBoost からの改善効 果に比べて無視できるほど小さかった，以上の結果にもと づき, 次節以降での GibbsBoost による顔検出器は, 確率 最大のサンプル系列 $\Theta_{S}^{*}$ で近似した場合について考える.

\section{5. 遮蔽状態判定}

\section{1 遮蔽状態の強度判定（遮蔽スコア）}

時刻 $t$ での入力画像 $D_{t}$ について，(5) 式の值が+1 とな る顔領域，すなわち，顔倹出結果の集合 $\left\{\Omega_{i} ; i \in I\right\}$ が得ら れたとする。検知対象についての条件 (1) と (2)より, 遮 蔽状態の強度（遮蔽スコア） $V_{t}$ を次式で定義する.

$$
\begin{aligned}
& V_{t}:=\max _{i \in I}\left[\lambda_{a} \phi\left(\frac{r_{i}}{r_{0}} ; \rho_{a}\right)+\lambda_{b} \phi\left(O_{i} ; \rho_{b}\right)\right], \\
& \phi(x ; \rho)= \begin{cases}0 & \text { if } x \leqq 0, \\
x / \rho & \text { if } 0<x<\rho, \\
1 & \text { otherwise. }\end{cases}
\end{aligned}
$$

ここで, $\phi(x ; \rho)$ は $\rho$ でパラメータ付けされたスコア関数で あり, 各々の重み $\lambda_{a}, \lambda_{b}$ は次式を満たすものとする.

$$
\lambda_{a}+\lambda_{b}=1 .
$$

また， $r_{0}$ は，顔領域の大きさ（半径）の基準値をあらわす。 $O_{i}$ は, $i$ 番目の顔領域 $\Omega_{i} \varepsilon$, 映像多重領域 $\Omega_{0}=\{(x, y)$ : $\left.x_{L} \leqq x \leqq x_{R}, y_{T} \leqq y \leqq y_{B}\right\}$ との空間的な重なりの度合 い（重畳度）をあらわす．(6) 式第 1 項は条件 (1) を，同式 第 2 項は条件 (2) を具体化したものである. 式 (7) に示す ように，顔領域の大きさ，および，重畳度が充分に大きい 
場合，遮蔽スコアは飽和すると仮定する.

重畳度 $O_{i}$ の最も単純な定義の一つは, 映像多重領域 $\Omega_{0}$ と顔領域 $\Omega_{i}$ とが重なる領域と, 顔領域 $\Omega_{i}$ 全体との面積比 で与兄られる (図 4 中段) 。

A uniform assumption on $O_{i}$

$$
O_{i}=\hat{O}_{i}:=\frac{1}{2 \pi r_{i}^{2}} \sum_{(x, y) \in \Omega_{0} \cap \Omega_{i}} \Delta_{S}(x, y) .
$$

ここで, $\Delta_{S}(x, y)=1$ は画像平面上の点 $(x, y)$ での単位面 積をあらわす。

顔領域 $\Omega_{i}$ は, 画像平面上の論理的に可能な顔候補領域 の走査の方法や, 近接した顔検出結果を一つにまとめる際 の後処理の影響を受けるため, その具体的な数值には原理 的に不確定な要素が含まれている. また, 顔の中心部分に は個人差や表情変化を捉える際に重要となる目や口などの 器官が集まっているため, 顔中心部の遮蔽は顔周辺部と比 較して視覚的な影響が大きいと考えられる。

本稿では，このような顔領域 $\Omega_{i}$ の不確定性と顔領域内 の視覚的な重要性の分布を考慮して, $O_{i}$ に新たな定義を与 える. まず, $i$ 番目の顔領域上のある画素 $(x, y)$ の顔全体に 対する視覚的な重要度を， $\Omega_{i}$ でパラメー夕付けされた正規 分布 $G\left(x, y ; \Omega_{i}\right)$ で表現する。 その上で, 映像多重領域 $\Omega_{0}$ 内の閉領域についての分布関数 $G\left(x, y ; \Omega_{i}\right)$ の積分值として $O_{i}$ を定義する（図 4 下段）.

\section{A Gaussian assumption on $\mathrm{O}_{i}$}

$$
\begin{gathered}
O_{i}=\tilde{O}_{i}:=\sum_{(x, y) \in \Omega_{0}} \Delta_{S}(x, y) \times G\left(x, y ; \Omega_{i}\right), \\
G\left(x, y ; \Omega_{i}\right)=\frac{1}{2 \pi \sigma_{r_{i}}^{2}} e^{-\frac{\left(x-x_{i}\right)^{2}+\left(y-y_{i}\right)^{2}}{2 \sigma_{r_{i}}^{2}}} \\
\sigma_{r_{i}}=\kappa r_{i} \quad(\kappa>0) .
\end{gathered}
$$

このとき, 分布関数 $G\left(x, y ; \Omega_{i}\right)$ は無限平面にわたる積分值 が 1 となるよう正規化されているため $0 \leqq \tilde{O}_{i} \leqq 1$ である.

\section{2 遮蔽スコアの平滑化とシステム応答}

条件 (3)より，一時的な遮蔽を検知対象から除外するた め, 遮蔽スコア $V_{t}$ を時間方向に平滑化し, 定常的な遮蔽 の強弱の指標（警告レベル） $U_{t}$ を定義する. 本方式では, カメラワークや被写体自身の運動に起因する一時的な遮蔽, あるいは，顔検出処理における検出エラーが突発的に発生 する傾向が強いことから, 長さ $\tau$ の $V_{t}$ の履歴に対してメ ディアンフィルタを施した值で $U_{t}$ を定義する.

$$
U_{t}:=\operatorname{MED}\left[V_{t-\tau+1}, . ., V_{t}\right] .
$$

$V_{t}$ の值域が $[0,1]$ であることから， $0 \leqq U_{t} \leqq 1$ である. た だし， $V_{t}=0(t<0), \tau=2 n+1\left(n \in \mathbf{Z}^{+}\right)$とする. 警 告レベル $U_{t}$ が閾值 $v$ を超えた場合, 連続して遮蔽が発生 したとみなし, 警告を発する。

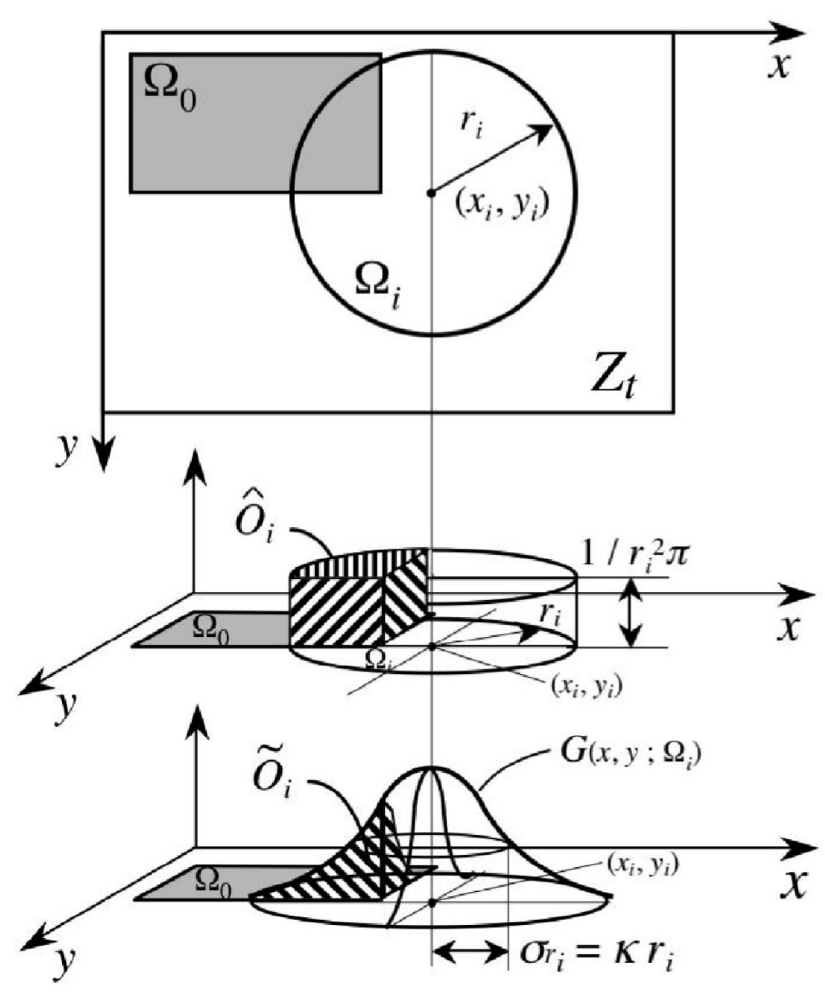

図 4 遮蔽状態判定パラメー夕と重畳度 $\hat{O}_{i}, \tilde{O}_{i}$ Occlusion parameters and overlap factor: $\hat{O}_{i}, \tilde{O}_{i}$.

なお， $U_{t}$ は $V_{t}$ に対して常に $(\tau-1) / 2[$ frame] だけ遅れる が，プローブ刺激法による精神作業負荷の測定に関する報 告 ${ }^{9)}$ によれば，注意を向けている情報源にまれな事象（す なわち，本研究における遮蔽状態）が生じると，その発生 から約 300〜 600[ms] 後に頭皮中心部から頭頂部にかけて 大きな反応が起こることが知られている.したがって, こ の時間方向の平滑化によるシステム応答の遅延が, 上記の 事象関連電位の潜時よりも短い数フレーム程度である場合, 本研究の目的である放送映像の監視業務においては, 実用 上ほとんど問題ない.

\section{6. 実 験と考察}

提案手法の性能を検証するため，NHK ニュース「首都 圈ネットワーク」（2006 年 8 月放送分）から検知対象の三 つの条件映像に合致する検知対象映像 10 シーンと, 一つ あるいは複数の条件に合致しない非検知対象映像 11 シー ンの, 計 21 シーンを抽出し, 評価データとした. 評価デー 夕の作成に際しては，シーン境界でのシステム応答（遅延） を明確にするため，前者と後者が交互に 1 秒間隔で並ぶよ うに編集した，正解データは，遅延がない理想的なシステ ムの応答，すなわち，検知対象のシーンに対して 1 を，そ れ以外のシーンでは 0 を出力する波形とした．顔画像検 出は, 画像処理ライブラリOpenCV ${ }^{10)}$ が提供する一般的 なブースト学習アルゴリズムで学習済みの顔検出器 (以下, OpenCV と略す) と, GibbsBoost で学習した顔検出器 ${ }^{8)}$ (以下, GibbsBoost と略す) を比較した. GibbsBoostの各 パラメータは, 文献 ${ }^{8)}$ に記載した内容と同一の設定にした. 


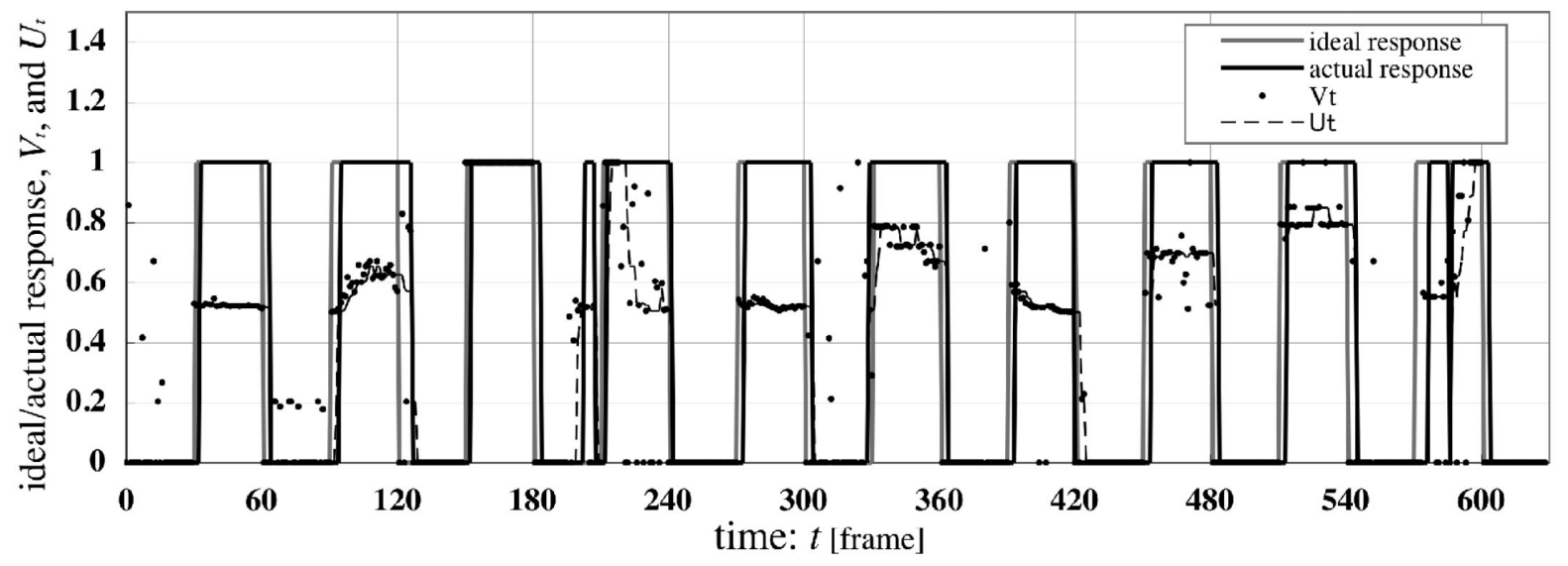

図 5 遮蔽状態の判定結果 (顔検出: GibssBoost, 重畳度 : Gaussian)

Trajectories of ideal response, actual response, $V_{t}$, and $U_{t}$ for the combination of GibbsBost-Gaussian.

遮蔽状態判定で用いる重畳度 $O_{i}$ は，(10) 式にもとづく場合 (以下, uniform と略す) と, (11) 式にもとづく場合（以下, Gaussian と略す)の 2 通りを実装した. 遮蔽状態判定の各 パラメー夕は，同ニュース番組（2006 年 7 月放送分）から 別途抽出した画像（検知対象映像 4 シーン, 非検出対象映 像 4 シーン）を用いて最適化した結果，次の值に設定した： $r_{0}=35,\left\{\left(x_{L}, y_{T}\right),\left(x_{R}, y_{B}\right)\right\}=\{(60,90),(190,150)\}$, $\rho_{a}=1.0, \rho_{b}=0.5, \lambda_{a}=\lambda_{b}=0.5, \kappa=0.25, \tau=7$ [frame], $v=0.5$.

各々の組合せについての評価デー夕全体に対する遮蔽状 態の判定結果を表 1 に示す。表 1 に示すように，誤検出 率（非検知対象を誤って検知した割合）はいずれも $10 \%$ 前 後でほぼ一定の值を示したが, 再現率（検知対象を正しく 検知した割合）については, 顔検出器を GibbsBoost アル ゴリズムで学習し，重畳度を定義式 (11) にもとづいて計 算した場合が最も高かった。放送素材映像の監視において は，遮蔽の危険がある映像を漏れなく検出することが重要 である。したがって，木方式を監視業務の補助ツールとし て利用する場合に打いては，再現率 $90 \%$ を唯一達成した GibbsBoost - Gaussian の組合せが今回実験を行った 4 通 りの組合せの中では最も適しているといえる。なお，今回 の実験結果をもとに現場の担当者と今後の方針について検 討した結果, 現時点で現場でも充分に利用可能なレベルで あるとの見解に達し，放送現場での実地検証にとりかかる 予定である。

本組合せ（GibbsBoost - Gaussian）についての, 遮蔽 スコア $V_{t}$ と警告レベル $U_{t}$ の時間推移の様子を図 5 に示 す。また，同組合せにおいて正しく検知された検知対象の 例と, 正しく棄却された非検知対象の例を図 6 と図 7 に 示す.

図 5 のグラフの時刻 $220<t<240$ および時刻 $570<$ $t<590$ 付近でみられる遮蔽スコア $V_{t}$ の不安定な挙動は, 人物が歩行中に顔の向きを横方向に振っているシーンと顔 が下にうつむいているシーンでの, 断続的な顔検出の失敗

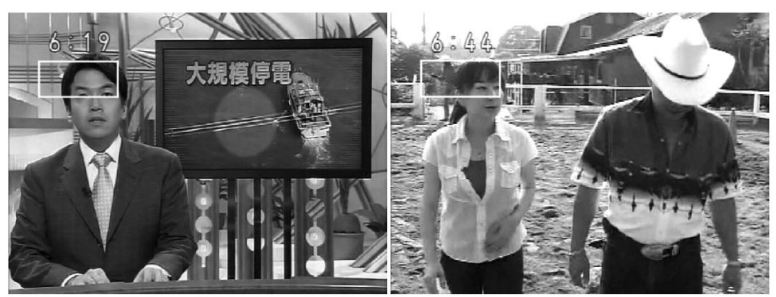

図 6 正しく検知された検知対象の例 (左: $t=100$, 右: $t=222$ ) Examples of true positives.

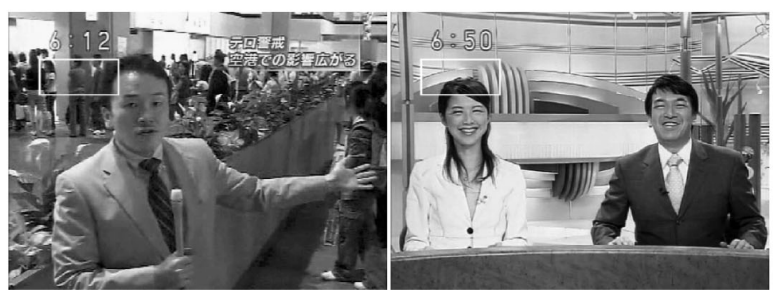

図 7 正しく棄却された非検知対象の例 (左: $t=0$, 右: $t=610$ ) Examples of true negatives.

が原因であった。これらの現象はいずれも顔検出器の顔の 向きに対する磒健性の不足に因るものであり, 様々な顔の 向きを含んだ画像で学習すれば回避可能である.

なお, OpenCV と GibbsBoost の顔検出処理の実行時の 計算コストは理論的に同じであり，様々な最適化の工夫が施 された前者の顔検出器での全体の処理速度は約 $2.5[\mathrm{fps}]$ で あったが，これは入力画像全体を探索した場合の実測值”で あり，被遮蔽領域から充分に遠い部分を顔検出時の探索空 間から除外すれば，計算コストは更に削減可能である.

表 1 遮蔽状態の判定結果

\begin{tabular}{c|c|c|c|c}
\multicolumn{3}{c|}{ Experimental results of face occlusion spotting. } \\
\hline 顔検出 & \multicolumn{2}{|c|}{ OpenCV } & \multicolumn{2}{c}{ GibbsBoost } \\
\hline 重畳度 & uniform & Gaussian & uniform & Gaussian \\
\hline 再現率 & $82.3 \%$ & $85.3 \%$ & $87.0 \%$ & $90.0 \%$ \\
\hline 䛊検出率 & $9.7 \%$ & $10.0 \%$ & $8.2 \%$ & $10.9 \%$ \\
\hline
\end{tabular}

\footnotetext{
*Intel, Xeon 3.8[GHz] CPU での実験結果
} 


\section{7.むすび}

確率的な集団学習アルゴリズム（GibbsBoost）にもとづ く顔画像検出と, 顔領域の境界の不確定性や被遮蔽時の視 覚的重要度の分布を考慮した遮蔽状態判定の組合せによる, 映像重畳時の顔遮蔽の自動検知法を提案した。

一般的なブースト学習アルゴリズムで学習した顔画像検 出器と, 顔検出結果を平滑化することなく, 直接的に評洒 する遮蔽状態判定法を比較刘象とした実験の結果，これら 決定論的なアプローチに対して, 本研究で提案した非決定 論的なアプローチにもとづく手法の組合せはほぼ同等の誤 検出率で約 $8 \%$ 再現率を改善した。

今後は, 横顔に対する検出精度や顔検出の処理速度など, 個々の要素技術の改善に取組むとともに，ユーザインタフ エースなど方式全体の最適化を検討し，放送現場での実用 化を目指したい.

なお，本研究の一部は科研費 (19700223) の援助を受け たものである.

\section{〔文献)}

1) H. A. Roweley, S. Baluja, and T. Kanade: "Neural network-based face detection," IEEE Trans. on PAMI, 20, 1, pp.23-38 (1998)

2) E. Osuna, R. Freund, and F. Girosi: "Training support vector machines: an application to face detection," Proc. of CVPR, pp.130-136 (1997)

3) C. P. Papageorgiou, M. Oren, and T. Poggio: "A general framework for object detection," Proc. of ICCV, pp.555-562 (1998)

4) P. Viola and M. Jones: "Rapid object detection using a boosted cascade of simple features," Proc. of CVPR, 1, pp.511-518 (2001)

5) Y. Freund and R. E. Schapire: "A decision-theoretic generalization of on-line leaerning and an application to boosting," Computational Learning Theory: Eurocolt, pp.23-37, Springer (1995)

6) A. Doucet, et. al. eds.: "Sequential Monte Carlo in Practice," Springer, New York (2001)

7) Y. Nakada, Y. Mouri, Y. Hongo, and T. Matsumoto: "GibbsBoost: a boosting algorithm using a sequential monte carlo approach," Proc. of MLSP, pp.259-264 (2006)

8）木村彰夫, 松井淳, 中田洋平, 松本隆: “GibbsBoost による正面顔画像 検出：事前情報を考慮する Bayes 的アプローチ,”第 5 回情報科学技術 フォーラム予稿集, I-008, pp.17-18 (2006)

9）入戸野宏：“映像に対する注意を測る-事象関連電位を用いたプローブ刺 激法の心用例-," 生理心理学と聖心生理学, 24, 1, pp.5-18 (2006)

10) R. Lienhart and J. Maydt: "An extended set of Haar-like features for rapid object detection," Proc. of ICIP, 1, pp.900-903 (2002)
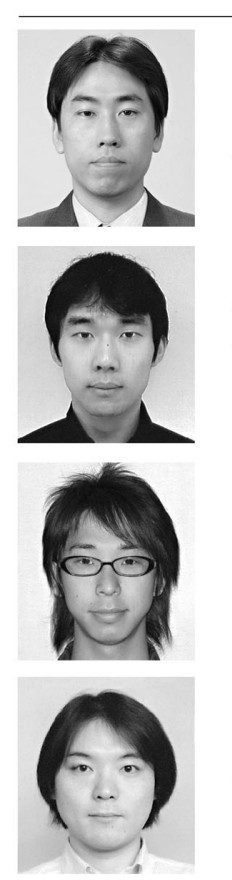

ま松井 淳 1994 年, 早稲田人学理工学部電気工 学科卒業，1996 年，同大学大学院修士課程修了。同年, NHK 入局。札幌放送局を経て，1998 年より同放送技術 研究所勤務. 音声認識, 画像認識の研究に從事. 2004 年, 早稲田大学大学院博士後期課程入学. (社会人特別選考). 正会員.

後藤变祐 2007 年, 早稲田大学理工学部電気・情 報生命工学科卒業. 現在, 同大学大学院理工学研究科に 在籍. 実習生として NHK 放送技術研究所にて, 機械学 習にもとづくパターン認識（顔画像検出）の研究に従事.

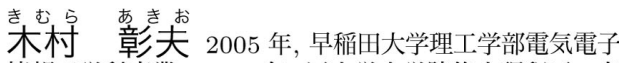
情報工学科卒業. 2007 年, 同大学大学院修士課程了. 在 学中, 機械学習にもとづくパターン認識（顔画像検出） の研究に従事.

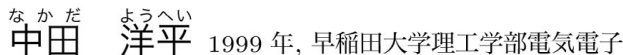
情報工学科卒業. 2001 年, 同大学大学院修士課程了. 現 在, 同大学大学院博士後期課程在学中。機械学習にもと づく信号・情報処理, パターン認識の研究に従事.

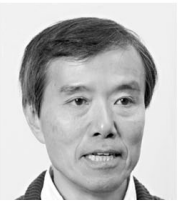

丟去杂䧄 1966 年, 早稲田大学理工学部電気工 学科卒業. 1970 年, ハーバード大学大学院応用数学修了. 1977 年〜1979 年, カリフォルニア大バークレー・電気 工学・計算機科学科研究員. 1980 年, 早稲田大学理工学 部電気工学科教授。2003 年〜2004 年, ケンブリッジ大 学研究員. 現在, 早榣田大学理工学術院教授。博士（工 学). IEEE 会員 (Fellow). 正会員.

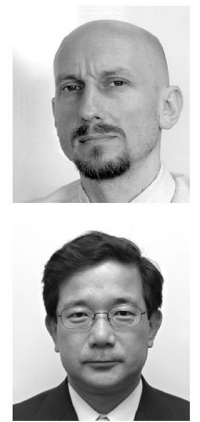

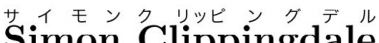

ンガム大学卒業. 1988 年, 英国ウォーリック大学博士課 程修了. 1996 年, NHK 入局. 同年上り同放送技術研究 所勤務。現在，放送技術研究所 (人間 - 情報) 知能処理 グループ主任研究員．画像認識の研究に従事．博上（工 学). 正会員.

㱏藤并真人 1983 年, 名古屋大学工学研究科電気 工学修士過程修了. 同年 NHK 入局. 1987 年, NHK 放 送技術研究所。1991 年, CMU 客員研究員. 1998 年, エイ・ティ・アール人間情報通信研究所窒長。2 001 年, NHK 放送技術研究所に復㷌. 現在, 同 (人間・ 情報) 知 能処理グループ主任研究員. 主に画像認識, 視覚のバイ オサイバネティクス，立体画像情報処理に関する研究に 従事. 正会員.

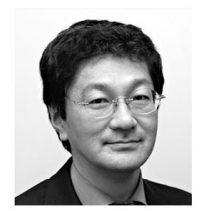

䒔茉 㖊行き 1980 年, 京都大学大学院電気工学専 攻修士課程修了. 同年 NHK (日本放送協会) 入局. 甲府 放送局，放送技術研究所，技術局，編成局を経て，現在， 放送技術研究所知能処理グループリーダー．2005 年〜東 京上業大学特任教授（兼任）。画像・映像・メディア情 報処理，コンピュータアーキテクチャ、コンテンツ制作 技術, ディジタル放送などの研究開発に從事. 工博. 正 会員. 